\title{
Changes in Physicochemical Characteristics during Fruit Development in June-bearing Strawberry Cultivars
}

\author{
Sung Kyeom Kim', Ro ${ }^{1} a \mathrm{Bae}^{2}$, Haeyoung $\mathrm{Na}^{3}$, Kwan Dal $\mathrm{Ko}^{4}$, and Changhoo Chun ${ }^{1,5^{*}}$ \\ ${ }^{1}$ Research Institute for Agriculture and Life Sciences, Seoul National University, Seoul 151-921, Korea \\ ${ }^{2}$ Korea Agency for Korea National Food Cluster, Ministry for Food, Agriculture, Forestry, \\ and Fisheries, Gwacheon 427-806, Korea \\ ${ }^{3}$ Department of Horticulture, Mokpo National University, Mokpo 534-729, Korea \\ ${ }^{4}$ Department of Horticultural Crop Research, National Institute of Horticultural \& Herbal Science, Suwon 440-706, Korea \\ ${ }^{5}$ Department of Plant Science, Seoul National University, Seoul 151-921, Korea \\ *Corresponding author: changhoo@snu.ac.kr
}

Received November 25, 2012 / Revised January 2, 2013 / Accepted January 2, 2013

(C) Korean Society for Horticultural Science and Springer 2013

\begin{abstract}
Changes in physicochemical characteristics were investigated during fruit development in 'Maehyang', 'Seolhyang', 'Keumhyang', 'Akihime', and 'Red Pearl' strawberries. Fresh weights and color parameters of strawberry fruits changed significantly during the fruit development in all cultivars. Fruit shapes of 'Maehyang' and 'Akihime' were conical, with an index of length to width being 1.5 and that of 'Seolhyang', 'Keumhyang', and 'Red Pearl' were cordate, the index being 1.3. Firmness decreased as the fruit developed in all cultivars. Contents of sugars, organic acids, ascorbic acid, and anthocyanin increased as the fruits developed while the ellagic acid content decreased. Sugars, ascorbic acid, and anthocyanin contents of 'Maehyang', 'Seolhyang', and 'Keumhyang' were higher than those of 'Akihime' and 'Red Pearl'. Results indicate that newly-bred Korean strawberry cultivars containing high levels of bioactive compounds were superior to major Japanese cultivars that have been broadly cultivated in East Asian countries.
\end{abstract}

Additional key words: anthocyanin, ascorbic acid, ellagic acid, organic acid, ripening, sugar

\section{Introduction}

Strawberries (Fragaria $\times$ ananassa Duch.) are classified as non-climacteric fruit, showing no increases in respiration rate and ethylene production during ripening (Biale and Young, 1981). The strawberry fruits are generally harvested at the fully matured stage since the ripening process does not normally continue after detachment (McGlasson, 1985). Several researchers revealed that strawberries can change red color during storage, even when harvested at the early fruit ripening stages but they do not sufficiently accumulate sugars and acids to reach an acceptable level for fresh consumption (Forney et al., 1998; Kalt et al., 1993; Spayd and Morris, 1981).

Ripening is a biochemical process in fruits, in which physical and chemical characteristics including dramatic bioactive compounds production, such as reducing sugars, organic acids, ascorbic acid, anthocyanin, and ellagic acid for each fruit stages at maturity. In general, strawberry fruits become softer, redder, and sweeter during the ripening process. Woodward (1972) reported that strawberry fruits had an initial phase of growth and enlargement followed by a maturation phase. Firmness, color, and the sugar/acid ratio are important determinants of overall quality in ripe strawberry fruits (Shamaila et al., 1992). The loss of firmness during the ripening is a major factor determining the strawberry fruit quality and postharvest shelf-life. The profile changes in numerous bioactive compounds in strawberry fruits are observed during ripening (Manning, 1994). The sugars and ascorbic acid contents increase rapidly until the fruit is fully ripened (Moing et al., 2001; Montero et al., 1996; Perkins- Veazie, 1995), however, the citric and malic acids declines gradually during fruit ripening (Hancock, 1999). Additionally, anthocyanin content of strawberry fruits increase, whereas the ellagic acid content decline during the ripening progress (Kosar et al., 2004; Williner et al., 2003).

Strawberries are highly regarded in the fresh fruit market, especially during the winter and early spring seasons in Korea. Korean-bred strawberry cultivars 'Maehyang', 'Seolhyang', and 'Keumhyang' are known to be suitable for forced culture, 
targeting for very early harvest, and have excellent qualities and storability. These cultivars were initially bred at Nonsan Strawberry Experiment Station in 2002 ('Maehyang') and 2006 ('Seolhyang' and 'Keumhyang'), and have since been distributed to growers. However, there is little information on their ripening characteristics. The objective of this study was to investigate the physicochemical characteristics during fruit development in five strawberry cultivars, three new Korean-bred, 'Maehyang', 'Seolhyang', and 'Keumhyang', and two Japanese cultivars, 'Akihime' and 'Red Pearl'.

\section{Materials and Methods}

\section{Production of Strawberry Fruit}

Three Korean cultivars 'Maehyang', 'Seolhyang', and 'Keumhyang', and two major Japanese cultivars 'Akihime' and 'Red Pearl' strawberry plants were grown at the Experimental Farm of Seoul National University, located in Suwon $\left(37^{\circ} 16^{\prime} 12^{\prime \prime} \mathrm{N}, 126^{\circ} 59^{\prime} 20^{\prime \prime} \mathrm{E}\right.$, and elevation $\left.30 \mathrm{~m}\right)$, Korea from September, 2008 to May, 2009. The cultivation type was hydroponic culture using drip irrigation systems in a greenhouse. The strawberry plants (90 days old) were transplanted in plastic containers $740 \mathrm{~mm} \times 250 \mathrm{~mm} \times 200 \mathrm{~mm}$ $(\mathrm{L} \times \mathrm{W} \times \mathrm{H}$, inside) filled with a mixture of peatmoss (BM-4, Berger Peat Moss Ltd., Quebec, Canada) and perlite (Parat No 3, Kyung Dong Ceratech Co., Ltd., Seoul, Korea) $(1: 1, \mathrm{v} / \mathrm{v})$. The planting density was 24 plants $/ \mathrm{m}^{2}$, and the plants were fertigated with $450 \mathrm{~mL}$ plant/day using Yamazaki's strawberry solution (Yamazaki, 1982). The Yamazaki's solution was composed of $303.3 \mathrm{mg} \cdot \mathrm{L}^{-1} \mathrm{KNO}_{3}, 236.2 \mathrm{mg} \cdot \mathrm{L}^{-1} \mathrm{Ca}\left(\mathrm{NO}_{3}\right)_{2}$. $4 \mathrm{H}_{2} \mathrm{O}, 57.5 \mathrm{mg} \cdot \mathrm{L}^{-1} \mathrm{NH}_{4} \mathrm{H}_{2} \mathrm{PO}_{4}$, and $123.2 \mathrm{mg} \cdot \mathrm{L}^{-1} \mathrm{MgSO}_{4}$. $7 \mathrm{H}_{2} \mathrm{O}$ as macroelements. Microelement composition were 3 $\mathrm{mg} \cdot \mathrm{L}^{-1} \mathrm{Fe}$ as Fe-EDTA, $0.5 \mathrm{mg} \cdot \mathrm{L}^{-1} \mathrm{H}_{3} \mathrm{BO}_{3}, 0.5 \mathrm{mg} \cdot \mathrm{L}^{-1}$ $\mathrm{MnSO}_{4} \cdot 4 \mathrm{H}_{2} \mathrm{O}, 0.05 \mathrm{mg} \cdot \mathrm{L}^{-1} \mathrm{ZnSO}_{4} \cdot 7 \mathrm{H}_{2} \mathrm{O}, 0.02 \mathrm{mg} \cdot \mathrm{L}^{-1} \mathrm{CuSO}_{4}$. $5 \mathrm{H}_{2} \mathrm{O}, 0.01 \mathrm{mg} \cdot \mathrm{L}^{-1} \mathrm{Na}_{2} \mathrm{MoO}_{4} \cdot 2 \mathrm{H}_{2} \mathrm{O}$.

Secondary or tertiary strawberry fruits in the third fruit cluster were sampled. Fruits were harvested at three stages of fruit development, expressed in color and days after anthesis (DAA); green (10 DAA), white (25 DAA), and red (40 DAA) stages. Ten random fruits were harvested at each developmental stage in each cultivar from different plants and five out of these ten fruits were used for chemical analyses. Each measurement had three replications, three separate extractions from three different fruit samples.

\section{Measurement of Physical Characteristics}

Fresh weight of fruits was measured using an electronic balance (PG203, Mettler-Toledo Inc., Switzerland), and length and width of fruits also were measured by a digital calipers (Series 500, Mitutoyo Co., Kawasaki, Japan). Firmness was measured using a texture analyzer (TA-XT2, Arrow Scientific, Lane Cove, Australia) and the penetration speed and depth were $10 \mathrm{~mm} \cdot \mathrm{s}^{-1}$ and $5 \mathrm{~mm}$, respectively. A $5 \mathrm{~mm}$ diameter cylinder type probe was used, and results were expressed as newton $(\mathrm{N})$. Fruit color was measured at the fruit surface using a color meter (CR-400, Minolta Co., Tokyo, Japan). Color was recorded using the CIE ( $\mathrm{L}^{*}, \mathrm{a}^{*}$, and $\mathrm{b}^{*}$ ) uniform color space, in which the $\mathrm{L}^{*}$ scale ranged from no reflection $\left(\mathrm{L}^{*}=0\right.$; black) to perfect diffuse reflection $\left(\mathrm{L}^{*}=100\right.$; white); the $\mathrm{a}^{*}$ scale ranged from negative values for green to positive values for red, and the $b^{*}$ scale ranged from negative values for blue to positive values for yellow. Numerical values of $a^{*}$ and $b^{*}$ were converted into the hue angle $(\mathrm{H}=$

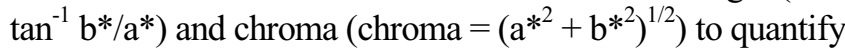
the intensity and purity of the hue, respectively (Francis, 1980).

\section{Extraction and Analysis of Sugars and Organic Acids}

Fruit sample $(5 \mathrm{~g})$ was homogenized with $20 \mathrm{~mL}$ of distilled water, filtered using an $8 \mu \mathrm{m}$ cellulose of the filter paper (Whatman International Ltd, Kent, UK) and filtered again through a $0.45 \mu \mathrm{m}$ polyvinylidene fluoride membrane of the syringe filter (Agilent Co., New York, USA). The filtrate was diluted and injected into a chromatography system (Dionex 2500, Dionex Co., New York, NY, USA). For sugar analysis, the solvent was $18 \mathrm{mM}$ sodium hydroxide at a flow of $1 \mathrm{~mL} \cdot \mathrm{min}^{-1}$. CarboPac PA10 $(4 \times 250 \mathrm{~mm}$ : Dionex Co., New York, NY, USA), and an amperometric detector with an $\mathrm{Au}$ electrode was used. Fructose and glucose content were calculated by using external standards. The same extract used in the sugar analysis was used in organic acid analysis. IonPac ICE-AS6 column $(9 \times 250$ mm; Dionex Co., New York, NY, USA) was used for separation of acids and $0.4 \mathrm{mM}$ heptafluorobutyric acid was used as an eluent at a flow rate $1 \mathrm{~mL} \cdot \mathrm{min}^{-1}$. A suppressed detector, with an anion-ICE micromembrane suppressor and $5 \mathrm{mN}$ tetrabutylammonium hydroxide was used. External standard was used to calculate organic acid content such as citric and malic acids.

\section{Extraction and Analysis of Ascorbic Acid}

The strawberry fruit sample (10 g) was homogenized with $50 \mathrm{~mL}$ of buffer solution (4\% metaphosphoric acid) and was filtered using an $8 \mu \mathrm{m}$ cellulose of the filter paper (Whatman International Ltd, Kent, UK). The mixture was filtered through a $0.45 \mu \mathrm{m}$ polyvinylidene fluoride membrane of the syringe filter (Agilent Co., New York, USA) and injected for L-ascorbic acid analysis into an HPLC system (Ultimate 3000, Dionex, Sunnyvale, CA, USA) under the following conditions. The mobile phase was acetonitrile and $50 \mathrm{mM}$ $\mathrm{NH}_{4} \mathrm{H}_{2} \mathrm{PO}_{4}(70: 30, \mathrm{v} / \mathrm{v})$, and the flow rate was $1.0 \mathrm{~mL} \cdot \mathrm{min}^{-1}$. The components were detected at $254 \mathrm{~nm}$. A C18 reverse phase column $(4.6 \times 250 \mathrm{~mm}, 0.5 \mu \mathrm{m}$; Supelcosil TM C-18, 
Supelco, Bellefonte, PA, USA) was used for analysis (Kim et al., 2006).

\section{Extraction and Analysis of Anthocyanin}

Anthocyanin was extracted from the fruit skin $(2 \mathrm{~g})$, less than $2 \mathrm{~mm}$ thick, by homogenizing with $5 \mathrm{~mL} \mathrm{HCl} \mathrm{(1 \% )-}$ methanol solution. The extract was filtered through an $8 \mu \mathrm{m}$ cellulose of the filter paper (Whatman International Ltd., Kent, UK) and measured with a spectrophotometer at 520 nm (UV-2550, Shimadzu, Kyoto, Japan). Total anthocyanin content was expressed as mg pelargonidin-3-glucoside ( $\varepsilon$ $\left.=36,000 \mathrm{~L} \cdot \mathrm{mol}^{-1} \cdot \mathrm{cm}^{-1}\right) 100 \mathrm{~g} \mathrm{FW}$ (Ferreyra et al., 2007).

\section{Extraction and Analysis of Ellagic Acid}

The strawberry fruit samples $(2.5 \mathrm{~g})$ were homogenized with purified water to $7.5 \mathrm{~mL}$ and $12.5 \mathrm{~mL}$ of methanol was added. Moreover, $5.0 \mathrm{~mL}$ of $6.0 \mathrm{~mol} \cdot \mathrm{L}^{-1} \mathrm{HCl}$ was added. The mixtures were refluxed for $2 \mathrm{~h}$ at $85^{\circ} \mathrm{C}$ and then were filtered through a $0.45 \mu \mathrm{m}$ polyvinylidene fluoride membrane of the syringe filter (Agilent Co., New York, USA) prior to injection into an HPLC system (Ultimate 3000, Dionex, Sunnyvale, CA, USA). Solvent A was $1 \%$ formic acid and solvent $\mathrm{B}$ was acetonitrile with $0.5 \mathrm{~mL} \cdot \mathrm{min}^{-1}$ flow rate. The gradient was: $0-15 \mathrm{~min}, 10-55 \%$ of $\mathrm{B}$ in $\mathrm{A} ; 15-20 \mathrm{~min}$, $55-100 \%$ of B in A; $20-25 \mathrm{~min}, 100-10 \%$ of $\mathrm{B}$ in $\mathrm{A} ; 25-35$ $\min , 10-10 \%$ of B in A. The peak was obtained UV/Vis detector at $260 \mathrm{~nm}$ by using C18 column $(4.6 \times 150 \mathrm{~mm}, 5$ $\mu \mathrm{m}$; Zorbax SB-C18, Agilent Co., New York, USA).

\section{Statistical Analysis}

Statistical analysis was applied to evaluate the existence of significant differences among strawberry cultivars and fruit development stages. Data of fresh weight, shape, firmness, and color of fruits, and sugar, organic acid, ascorbic acid, anthocyanin, and ellagic acid contents were analyze using Two-way factorial analysis of variance (ANOVA). Significant differences were determined at $P \leq 0.05,0.01$, and $0.001 \%$ levels.

\section{Results and Discussion}

\section{Physical Characteristics}

Fresh weight, length, width, shape index, and firmness of strawberry fruits were significantly different among fruit development stages and cultivars (Table 1). Fresh weights of all the tested strawberry cultivars at the green stage were less than $1.5 \mathrm{~g}$. However, the weight of strawberries at the white stage ranged between 8.7 and $11.7 \mathrm{~g}$, which was 9- to 11-fold greater than weights of the green stage fruits. Strawberry fruit growth as a function of time fits a single

Table 1. Changes in weight, length, width, shape index, and firmness during fruit development in five strawberry cultivars.

\begin{tabular}{|c|c|c|c|c|c|c|}
\hline Cultivar & $\mathrm{FDS}^{\mathrm{z}}$ & Weight (g) & Length (mm) & Width (mm) & Shape index & Firmness (N) \\
\hline \multirow[t]{3}{*}{ Maehyang } & Green & $1.1 \mathrm{~g}^{\mathrm{x}}$ & $17.2 \mathrm{~g}$ & $11.9 \mathrm{~g}^{\mathrm{h}}$ & $1.4 \mathrm{c}$ & $8.9 \mathrm{c}$ \\
\hline & White & $8.7 \mathrm{f}$ & $36.4 \mathrm{f}$ & $24.5 \mathrm{e}$ & $1.5 \mathrm{c}$ & $2.6 \mathrm{e}$ \\
\hline & Red & $21.9 \mathrm{c}$ & $52.1 \mathrm{~b}$ & $34.5 \mathrm{c}$ & $1.5 \mathrm{c}$ & $0.6 \mathrm{f}$ \\
\hline \multirow[t]{3}{*}{ Seolhyang } & Green & $1.5 \mathrm{~g}$ & $17.1 \mathrm{~g}$ & $13.9 \mathrm{f}$ & 1.2 ef & $8.4 \mathrm{c}$ \\
\hline & White & $11.7 \mathrm{~d}$ & $37.2 \mathrm{f}$ & $29.5 d$ & 1.3 def & $2.9 \mathrm{e}$ \\
\hline & Red & $26.4 \mathrm{~b}$ & $44.5 \mathrm{~d}$ & $39.0 \mathrm{a}$ & $1.1 \mathrm{~g}$ & $0.6 \mathrm{f}$ \\
\hline \multirow[t]{3}{*}{ Keumhyang } & Green & $1.1 \mathrm{~g}$ & $17.7 \mathrm{~g}$ & $13.4 \mathrm{fg}$ & $1.3 \mathrm{de}$ & $11.6 \mathrm{a}$ \\
\hline & White & $8.7 \mathrm{f}$ & $36.1 \mathrm{f}$ & $25.2 \mathrm{e}$ & $1.4 \mathrm{c}$ & $2.8 \mathrm{e}$ \\
\hline & Red & $32.6 \mathrm{a}$ & $53.7 \mathrm{ab}$ & $40.1 \mathrm{a}$ & $1.3 \mathrm{~d}$ & $0.6 \mathrm{f}$ \\
\hline \multirow[t]{3}{*}{ Akihime } & Green & $1.0 \mathrm{~g}$ & $18.4 \mathrm{~g}$ & $11.5 \mathrm{~h}$ & $1.6 \mathrm{~b}$ & $9.9 \mathrm{~b}$ \\
\hline & White & 9.5 ef & $41.7 \mathrm{e}$ & $24.4 \mathrm{e}$ & $1.7 \mathrm{a}$ & $3.8 \mathrm{~d}$ \\
\hline & Red & $27.8 \mathrm{~b}$ & 55.3 a & $36.8 \mathrm{~b}$ & $1.5 \mathrm{c}$ & $0.6 \mathrm{f}$ \\
\hline \multirow[t]{3}{*}{ Red Pearl } & Green & $1.1 \mathrm{~g}$ & $16.6 \mathrm{~g}$ & $12.7 \mathrm{fgh}$ & $1.3 \mathrm{de}$ & $10.2 b$ \\
\hline & White & $11.2 \mathrm{de}$ & $36.7 \mathrm{f}$ & $28.2 \mathrm{~d}$ & $1.3 \mathrm{def}$ & $2.4 \mathrm{e}$ \\
\hline & Red & $27.3 \mathrm{~b}$ & $47.7 \mathrm{c}$ & $39.3 \mathrm{a}$ & $1.2 \mathrm{fg}$ & $0.5 \mathrm{f}$ \\
\hline \multicolumn{7}{|l|}{ Significance } \\
\hline Cultivar (A) & & $* * *$ & $\star * \star$ & $* * *$ & $* * *$ & $* * *$ \\
\hline FDS (B) & & $* * *$ & $* * *$ & $* * *$ & $* * *$ & $* * *$ \\
\hline $\mathrm{A} \times \mathrm{B}$ interaction & & $* * *$ & $* * *$ & $* * *$ & $* *$ & $* * *$ \\
\hline
\end{tabular}

${ }^{\mathrm{z} F D S}$, fruit development stage.

${ }^{y}$ Shape index: Fruit length to width.

${ }^{\times}$Mean separation within columns according to Duncan's multiple range test at a $5 \%$ significance level.

Significant at $P=0.01$ or $0.001 \%$ level, respectively. 
sigmoid curve or was biphasic, depending on the cultivar (Miura et al., 1994; Mudge et al., 1981; Stutte and Darnell, 1987). Cells in the cortex and pith were responsible for most of the receptacle growth, with the cortex being the primary contributor to the fruit size (Hancock, 1999). Cell division accounted for only $15-20 \%$ of the total growth, occurring mostly prior to anthesis. The rest of the growth was a result of cell enlargement, with cell size increasing toward the inner part of the fruit. The fruit development was affected by numerous factors including the number and development of achenes on the receptacle (Moore et al., 1970).

Fruit shape of 'Maehyang' and 'Akihime' was conical, showing an index of length to width of 1.5 , whereas that of 'Seolhyang', 'Keumhyang', and 'Red Pearl' was cordate, with a ratio of 1.3. Perkins-Veazie (1995) reported that strawberry fruits tended to increase more in length than in width in European cultivars, but the fruit growth tendency of 'Seolhyang', 'Keumhyang', and 'Red Pearl', the conical shape of fruits, was opposite. Fruit shapes were the major characteristic for the classification of cultivars (Kim et al., 2009). The shape was affected by the number of achenes pollinated, temperature at time of planting or during fruit set, and plant nutrition (Albregts and Howard, 1982; Dana, 1980; Darrow, 1966).

Significant differences were found across the fruit develop- ment stages regarding the firmness. The firmness decreased as fruits developed. The firmnesses at the green stage were greater than $8.4 \mathrm{~N}$. Firmness of strawberries at the white stage ranged from 2.4-3.8 N. Strawberry fruits soften greatly between the green and white ripeness stages and continue to soften as color development progresses (Perkins-Veazie, 1995). It appears that much of softening results from the degradation of the middle lamella in the walls of the cortical parenchyma cells with increased release of pectins (Abeles and Takeda, 1990). Woodward (1972) also found that water-soluble pectin levels were very low at 14 DAA and increased to $90 \%$ of the total pectin level by 42 DAA.

Table 2 shows the mean values of the CIELAB colorimetric parameters obtained for the five cultivars of strawberry studied at the different fruit development stages. Fruit color parameters were significantly different among the fruit development stages and cultivars. The $b^{*}$ values of strawberry fruits dramatically decreased, whereas $a^{*}$ values rapidly increased with increasing fruit development stage. Changes in $a^{*}$ and $b^{*}$ values showed that the strawberry color changed from green to red as maturity increased (Little, 1975; Ménager et al., 2004). Net syntheses of chlorophyll and carotenoid pigments occurred up to $28 \mathrm{DAA}$, and anthocyanin synthesis commenced 28 to 35 DAA (Woodward, 1972). Thus, there was degradation of chlorophyll, consistent

Table 2. Changes in external color of fruits during fruit development in five strawberry cultivars.

\begin{tabular}{|c|c|c|c|c|c|c|}
\hline Cultivar & $\mathrm{FDS}^{\mathrm{z}}$ & L & $a^{*}$ & $b^{*}$ & Heu $\left({ }^{\circ}\right)$ & Chroma \\
\hline \multirow[t]{3}{*}{ Maehyang } & Green & $55.2 d^{y}$ & $-15.7 \mathrm{~g}$ & $36.9 \mathrm{~b}$ & $113.0 \mathrm{a}$ & $40.1 d$ \\
\hline & White & 70.2 a & -9.8 e & $28.0 \mathrm{~d}$ & $109.1 \mathrm{bc}$ & $29.7 \mathrm{f}$ \\
\hline & Red & $31.8 \mathrm{~g}$ & $35.1 \mathrm{c}$ & $15.3 \mathrm{~g}$ & $23.4 \mathrm{~h}$ & $38.3 \mathrm{~d}$ \\
\hline \multirow[t]{3}{*}{ Seolhyang } & Green & $59.4 \mathrm{c}$ & $-14.0 \mathrm{~g}$ & $35.2 \mathrm{~b}$ & $111.7 \mathrm{a}$ & $37.9 \mathrm{~d}$ \\
\hline & White & $68.2 a b$ & -10.3 ef & $30.8 \mathrm{c}$ & $108.3 \mathrm{c}$ & $32.6 \mathrm{e}$ \\
\hline & Red & $35.2 \mathrm{f}$ & 39.9 a & $23.8 \mathrm{e}$ & $30.4 \mathrm{f}$ & $46.7 \mathrm{a}$ \\
\hline \multirow[t]{3}{*}{ Keumhyang } & Green & $52.5 \mathrm{e}$ & $-15.6 \mathrm{~g}$ & $37.8 \mathrm{~b}$ & $112.5 \mathrm{a}$ & $40.9 \mathrm{~cd}$ \\
\hline & White & $68.7 \mathrm{ab}$ & $-7.2 \mathrm{~d}$ & $27.6 \mathrm{~d}$ & $104.6 \mathrm{e}$ & $28.6 \mathrm{f}$ \\
\hline & Red & $32.7 \mathrm{fg}$ & $38.4 a b$ & $20.4 \mathrm{f}$ & $27.2 \mathrm{~g}$ & $43.7 \mathrm{bc}$ \\
\hline \multirow[t]{3}{*}{ Akihime } & Green & $51.2 \mathrm{e}$ & $-15.2 \mathrm{~g}$ & $36.9 \mathrm{~b}$ & $112.4 \mathrm{a}$ & $40.0 \mathrm{~d}$ \\
\hline & White & $67.4 \mathrm{~b}$ & $-8.0 \mathrm{~d}$ & $28.2 \mathrm{~cd}$ & $105.8 \mathrm{de}$ & $29.3 \mathrm{f}$ \\
\hline & Red & $34.1 \mathrm{fg}$ & $38.1 \mathrm{~b}$ & 22.3 ef & $30.0 \mathrm{f}$ & $44.2 \mathrm{ab}$ \\
\hline \multirow[t]{3}{*}{ Red Pearl } & Green & $55.3 d$ & $-15.5 \mathrm{~g}$ & $40.5 \mathrm{a}$ & $111.0 \mathrm{ab}$ & $43.4 \mathrm{bc}$ \\
\hline & White & $66.9 \mathrm{~b}$ & $-11.5 f$ & 36.3 b & $107.6 \mathrm{~cd}$ & $38.1 \mathrm{~d}$ \\
\hline & Red & $33.7 \mathrm{fg}$ & $37.8 \mathrm{~b}$ & 21.8 ef & $29.6 \mathrm{f}$ & $43.9 \mathrm{ab}$ \\
\hline \multicolumn{7}{|l|}{ Significance } \\
\hline \multicolumn{2}{|l|}{ Cultivar (A) } & $* *$ & $* * *$ & $* * *$ & * & $* * *$ \\
\hline \multicolumn{2}{|c|}{ FDS (B) } & $* * *$ & $* * *$ & $* * *$ & $* * *$ & $* * *$ \\
\hline \multicolumn{2}{|c|}{$\mathrm{A} \times \mathrm{B}$ interaction } & $* \star *$ & $* * *$ & $* * *$ & $* * *$ & $* * *$ \\
\hline
\end{tabular}

${ }^{z}$ FDS, fruit development stage.

${ }^{y}$ Mean separation within columns according to Duncan's multiple range test at a $5 \%$ significance level.

Significant at $P=0.05,0.01$ or $0.001 \%$ level, respectively. 
with the disappearance of the chloroplasts and a decrease in the carotenoid content during strawberry ripening (Schwab and Raab, 2004). Perkins-Veazie and Huber (1987) reported that strawberry fruits ripen from white to red after 5-10 days in the field, depending on air temperature. In the present study, changes in $L^{*}, a^{*}, b^{*}$, Hue, and chroma values also indicate that strawberry surface color shifts from green to red at about 40 DAA.

\section{Sugars and Organic Acids Contents}

The fructose and glucose contents were significantly different among the fruit development stages (Table 3). Those contents of strawberries significantly increased as fruits developed. There was a unique characteristic regarding changes in sugars contents of 'Keumhyang' and 'Red Pearl' during fruit development. The amount of sugar accumulation of 'Keumhyang' was less than other cultivars but that of 'Red Pearl' strawberries was already high at the white stage. Thus 'Keumhyang' should be harvested at the fully ripen stage but 'Red Pearl' strawberries can be harvested at early ripe stages. Fructose and glucose contents of 'Keumhyang' at the red stage were 20.7 and $34.2 \mathrm{mg} \cdot \mathrm{g}^{-1} \mathrm{FW}$, respectively, showing the highest contents among all the tested cultivars. Fructose and glucose were predominant over sucrose, and the total sugar content could change during the growing period; however, the proportion of each sugar remains constant, even for different growing conditions and cultivars (Forney et al., 2000; Woodward, 1972).

The citric and malic acids contents were significantly different among cultivars and fruit development stages. Citric acid was not detected in any of the tested cultivars at the green stage, but was detected in 'Seolhyang' and 'Red Pearl' at the white stage. The citric acid contents of all of the tested cultivars ranged from 4.5 to $8.9 \mathrm{mg} \cdot \mathrm{g}^{-1} \mathrm{FW}$ at the red stage, with that of 'Red Pearl' at the red stage being the highest among all of the tested cultivars. Malic acid was not detected in any of the tested cultivars at the green and white stages. Malic acid content of all the tested cultivars ranged from 1.0 to $2.6 \mathrm{mg} \cdot \mathrm{g}^{-1} \mathrm{FW}$ at the red stage. The malic acid content of 'Maehyang' at the red stage was the greatest among all the tested cultivars. Organic acids were minor components of strawberry fruit, but they were important components for the taste in combination with sugars, acting on the sensory quality of strawberry fruit (Wang and Lin, 2000). The primary organic acid was citric acid, which ranges from 4 to $12 \mathrm{mg} \cdot \mathrm{g}^{-1} \mathrm{FW}$, comprises $88 \%$ of total acids (Perkins-Vaezie, 1995), and attributes greatly to fruit titratable acidity, which declines gradually during maturation (Hancock,

Table 3. Changes in sugars and organic acids contents of fruits during fruit development in five strawberry cultivars.

\begin{tabular}{|c|c|c|c|c|c|}
\hline \multirow{2}{*}{ Cultivar } & \multirow{2}{*}{$\mathrm{FDS}^{z}$} & \multicolumn{2}{|c|}{ Sugars content $\left(\mathrm{mg} \cdot \mathrm{g}^{-1} \mathrm{FW}\right)$} & \multicolumn{2}{|c|}{ Organic acids content $\left(\mathrm{mg} \cdot \mathrm{g}^{-1} \mathrm{FW}\right)$} \\
\hline & & Glucose & Fructose & Citric acid & Malic acid \\
\hline \multirow[t]{3}{*}{ Maehyang } & Green & $0.9 e^{y}$ & $2.2 \mathrm{e}$ & $-x$ & - \\
\hline & White & $4.6 \mathrm{~d}$ & $11.7 \mathrm{~d}$ & - & - \\
\hline & Red & $16.7 \mathrm{~b}$ & $29.1 \mathrm{abc}$ & $5.3 \mathrm{~cd}$ & $2.6 \mathrm{a}$ \\
\hline \multirow[t]{3}{*}{ Seolhyang } & Green & $1.0 \mathrm{e}$ & $2.2 \mathrm{e}$ & - & - \\
\hline & White & $5.0 \mathrm{~d}$ & $12.7 \mathrm{~d}$ & $4.5 \mathrm{~d}$ & - \\
\hline & Red & $18.1 \mathrm{ab}$ & $25.2 \mathrm{bc}$ & $6.2 \mathrm{bc}$ & $1.0 \mathrm{c}$ \\
\hline \multirow[t]{3}{*}{ Keumhyang } & Green & $1.1 \mathrm{e}$ & $2.7 \mathrm{e}$ & - & - \\
\hline & White & $2.4 \mathrm{de}$ & $5.0 \mathrm{e}$ & - & - \\
\hline & Red & 20.7 a & $34.2 \mathrm{a}$ & $6.9 \mathrm{~b}$ & $1.8 \mathrm{~b}$ \\
\hline \multirow[t]{3}{*}{ Akihime } & Green & $0.7 \mathrm{e}$ & $1.6 \mathrm{e}$ & - & - \\
\hline & White & $5.5 \mathrm{~d}$ & $12.0 \mathrm{~d}$ & - & - \\
\hline & Red & $20.4 a$ & $31.3 a b$ & $8.4 \mathrm{a}$ & $1.0 \mathrm{c}$ \\
\hline \multirow[t]{3}{*}{ Red Pearl } & Green & $0.9 \mathrm{e}$ & $2.3 \mathrm{e}$ & - & - \\
\hline & White & $9.2 \mathrm{c}$ & $15.8 \mathrm{~d}$ & $3.2 \mathrm{e}$ & - \\
\hline & Red & $15.1 \mathrm{~b}$ & $24.4 \mathrm{c}$ & 8.9 a & $1.6 \mathrm{~b}$ \\
\hline \multicolumn{6}{|l|}{ Significance } \\
\hline Cultivar (A) & & ns & ns & $* \star *$ & $* \star *$ \\
\hline FDS (B) & & $* * *$ & $* * *$ & $* * *$ & $* * *$ \\
\hline$A \times B$ interaction & & $\star *$ & $* *$ & $* * *$ & $* * *$ \\
\hline
\end{tabular}

${ }^{\mathrm{z}} \mathrm{FDS}$, fruit development stage.

${ }^{y}$ Mean separation within columns according to Duncan's multiple range test at a $5 \%$ significance level.

${ }^{x}$ Not detected.

$\stackrel{\mathrm{ns},+*,+\infty+N}{*}$ Nonsignificant or significant at $P=0.05,0.01$ or $0.001 \%$ level, respectively. 
1999). A good and well-balanced flavor of strawberry fruit is based on a high sugar and low acid (Perkins-Vaezie, 1995) and the higher sugar/acid implies a better taste.

\section{Ascorbic Acid Content}

Significant differences in ascorbic acid content were found among cultivars and fruit development stages (Fig. 1). Ascorbic acid content of all tested cultivars at the red stage ranged from 21.7 to $62.9 \mathrm{mg} \cdot 100 \mathrm{~g}^{-1} \mathrm{FW}$, showing the highest level observed at white and red fruit development stages. The increased ascorbic acid content according to the ripening stage was similar to the previous studies (Nascimento et al, 2005; Olsson et al., 2004; Spayd and Morris, 1981). Ascorbic acid contents were different up to 2.9-fold at the red stage among cultivars, which also varied according to development stage. It was reported that a strawberry fruit contains a large amount of ascorbic acid, $60 \mathrm{mg} \cdot 100 \mathrm{~g}^{-1} \mathrm{FW}$ on average; however the amount varies by cultivar (Bordonaba and Terry, 2010; Pozo-Insfran et al., 2006; Sturm et al., 2003). The ascorbic acid content of 'Maehyang' at the red stage was $62.9 \mathrm{mg} \cdot 100 \mathrm{~g}^{-1} \mathrm{FW}$, showing the highest value among all of the tested cultivars. Ascorbic acid content of 'Akihime' at the white stage was $29.4 \mathrm{mg} \cdot 100 \mathrm{~g}^{-1} \mathrm{FW}$, showing the highest value among all of the tested cultivars. Thinned or discarded strawberry fruits, especially white stage fruits of 'Akihime' could be used as a natural additive for the production of processed foods.

\section{Anthocyanin Content}

There were significant differences in anthocyanin content among cultivars and fruit development stages (Fig. 2). The anthocyanin contents of all tested strawberry cultivars were

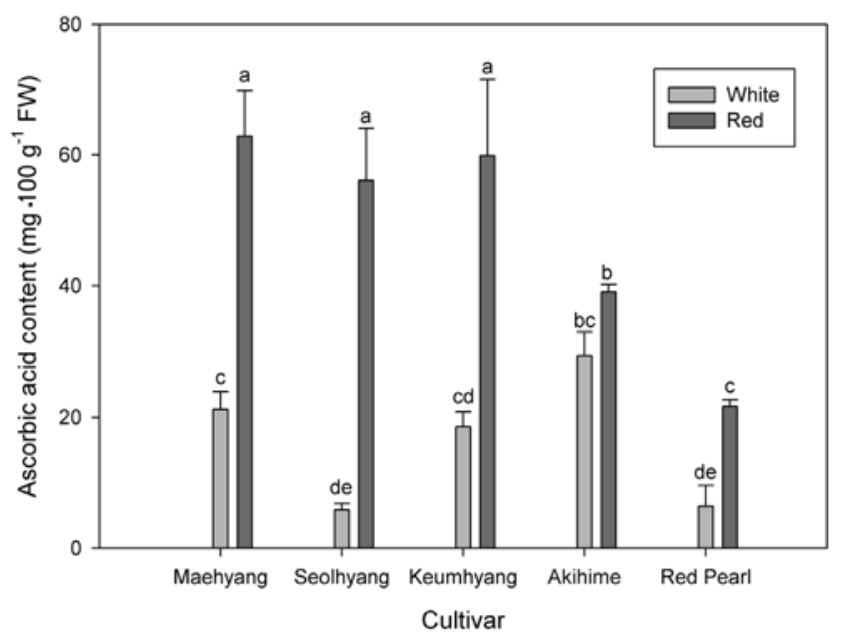

Fig. 1. Changes in ascorbic acid content of fruits during fruit development in five strawberry cultivars. Vertical bars show standard deviation $(n=3)$. Small letters inside the figure indicate mean separation by Duncan's multiple range test at $p \leq 0.05$. less than $2.3 \mathrm{mg} \cdot 100 \mathrm{~g}^{-1} \mathrm{FW}$ at green and white stages. However, the anthocyanin content of strawberries at the red stage ranged from $38.3-60.8 \mathrm{mg} \cdot 100 \mathrm{~g}^{-1} \mathrm{FW}, 16.7$ - to 26.4 fold greater than that of early fruit development stages. An increase in anthocyanin content with increasing ripening stages is in agreement with the data from other studies (Kosar et al., 2004; Yoshida et al., 2002). 'Keumhyang' at the red stage had the highest anthocyanin content of all experiment cultivars. Among the cultivars, there was an up to two-fold difference in anthocyanin content, which also varied according to the fruit development stage.

\section{Ellagic Acid Content}

Ellagic acid contents were significantly different among fruit development stages (Fig. 3). The ellagic acid contents of all the tested strawberry cultivars were less than $4.8 \mathrm{mg}$. $100 \mathrm{~g}^{-1} \mathrm{FW}$ at the red stage. However, the ellagic acid content of strawberries at the green stage ranged from 30.6-42.5 mg $\cdot 100 \mathrm{~g}^{-1} \mathrm{FW}, 6-9$-fold more than that of mature stage. Previously, ellagic acid had been reported generally as the main compound in green strawberry fruit and the decrease in ellagic acid with progression of ripening stage is in agreement with results from other studies (Williner et al., 2003). The ellagic acid content of 'Red Pearl' at the green stage was higher than that of any of the other tested cultivars. Ellagic acid content of 'Maehyang' at the white stage was $20.8 \mathrm{mg} \cdot 100 \mathrm{~g}^{-1} \mathrm{FW}$, showing the highest value among all the tested cultivars at the same fruit development stage. Because of high ellagic acid contents in green fruits, thinned or discarded strawberry fruits at the white stage of 'Maehyang' could be used as a natural additive for developing anticarcinogen foods.

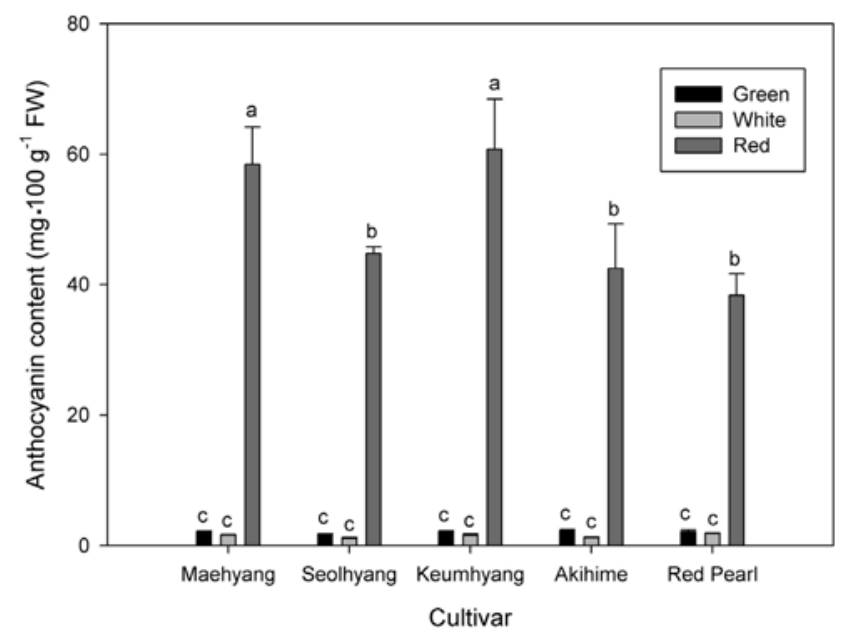

Fig. 2. Changes in anthocyanin content of fruits during fruit development in five strawberry cultivars. Vertical bars show standard deviation $(n=3)$. Small letters inside the figure indicate mean separation by Duncan's multiple range test at $p \leq 0.05$. 


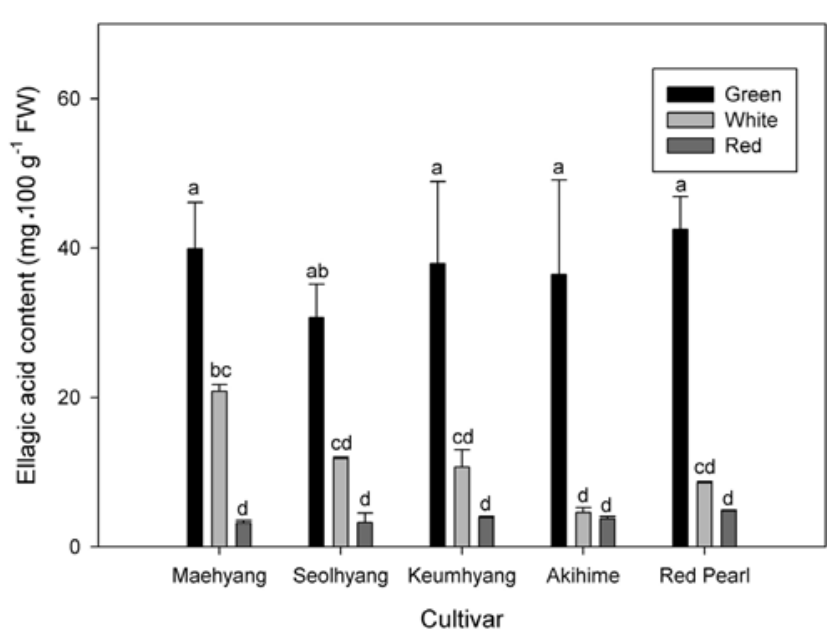

Fig. 3. Changes in ellagic acid content of fruits during fruit development in five strawberry cultivars. Vertical bars show standard deviation $(n=3)$. Small letters inside the figure indicate mean separation by Duncan's multiple range test at $p \leq 0.05$.

Physicochemical characteristics of newly-bred Korean strawberry cultivars were investigated during fruit development. Determination of the timing and nature of the biochemical differences observed among cultivars should provide information on the metabolic origins of these differences. Information on the ripening characteristic of each cultivar might be used to develop postharvest handling and storage techniques. In addition, our data indicate that domestic market consumers would accept those cultivars as equal or better cultivars as compared to the Japanese cultivars. The data we acquired from the present study could also be valuable to promote cultivars, and to utilize discarded fruits in early mature stages for processed food.

Acknowledgment: This work was carried out with the support of "Cooperative Research Program for Agriculture Science \& Technology Development (Project No. 907002082012)" Rural Development Administration, Republic of Korea.

\section{Literature Cited}

Abeles, F.B. and F. Takeda. 1990. Cellulase activity and ethylene in ripening strawberry and apple fruits. Sci. Hort. 42:269-275.

Albregts, E.E. and C.M. Howard. 1982. Effect of fertilizer rate on number of malformed strawberry fruit. Proc. Fla. State Hort. Soc. 95:323-324.

Biale, J.B. and R.E. Young. 1981. Respiration and ripening in fruitsretrospect and prospect, p. 1-39. In: J. Friend and M.J.C. Rhodes (eds.). Recent advances in the biochemistry of fruits and vegetables. Academic Press, London, UK.

Bordonaba, J.G. and L.A. Terry. 2010. Manipulating the taste-related composition of strawberry fruits (Fragaria $\times$ ananassa) from different cultivars using deficit irrigation. Food Chem. 122:1020-1026.

Dana, M.N. 1980. The strawberry plant and its environment, p. 33-44. In: N.F. Childers (ed.). The strawberry: Varieties, culture, pests and control, storage, marketing. Horticultural Publications, Gainesville,
FL.

Darrow, G.M. 1966. The strawbery. Holt, Rinehart \& Winston, New York.

Ferreyra, R.M., S.Z. Viña, A. Mugridge, and A.R. Chaves. 2007. Growth and ripening season effects on antioxidant capacity of strawberry cultivar Selva. Sci. Hort. 112:27-32.

Forney, C.F., W. Kalt, and M.A. Jordan. 2000. The composition of strawberry aroma is influenced by cultivar, maturity, and storage. HortScience 35:1022-1026.

Forney, C.F., W. Kalt, J.E. McDonald, and M.A. Jordan. 1998. Changes in strawberry fruit quality during ripening on and off the plant. Acta Hort. 464:506. (Abstr.)

Francis, F.J. 1980. Color quality evaluation of horticultural crops. HortScience 15:58-59.

Hancock, J.F. 1999. Strawberries. CABI Publishing, Wallingford, UK.

Kalt, W., R.K. Prange, and P.D. Lidster. 1993. Postharvest color development of strawberries influence of maturity, temperature and light. Can. J. Plant Sci. 73:541-548.

Kim, D.Y., M.K. Yoon, J.H. Kwak, T.I. Kim, and J.H. Kim. 2009. Classification of strawberry germplasms based on horticultural traits and principal component analysis. Kor. J. Hort. Sci. Technol. 27:636-643.

Kim, S., K.S. Kim, and J.B. Park. 2006. Changes of various chemical components by the difference of the degree of ripening and harvesting factors in two single-harvested peppers (Capsicum annuum L.). Kor. J. Food Sci. Tehcnol. 38:615-620.

Kosar, M., E. Kafkas, S. Paydas, and K.H.C. Baser. 2004. Phenolic composition of strawberry genotypes at different maturation stages. J. Agr. Food Chem. 52:1586-1589.

Little, A.C. 1975. Off on a tangent. J. Food Sci. 40:410-411.

Manning, K. 1994. Changes in gene expression during strawberry fruit ripening and their regulation by auxin. Planta 194:62-68.

McGlasson, W.B. 1985. Ethylene and fruit ripening. HortScience 20:51-54.

Ménager, I., M. Jost, and C. Aubert. 2004. Changes in physicochemical characteristics and volatile constituents of strawberry (cv. Cigaline) during maturation. J. Agr. Food Chem. 52:1248-1254.

Miura, H., M. Yoshida, and A. Yamasaki. 1994. Effect of temperature on the size of strawberry fruit. J. Jpn. Soc. Hort. Sci. 62:769-774.

Moing, A., C. Renaud, M. Gaudillere, P. Raymond, P. Roudeillac, and B. Denoyes-Rothan. 2001. Biochemical changes during fruit development of four strawberry cultivars. J. Amer. Soc. Hort. Sci. 126:394-403.

Montero, T.M., E.M. Mollá, R.M. Esteban, and F.J. López-Andréu. 1996. Quality attributes of strawberry during ripening. Sci. Hort. 65:239-250.

Moore, J.N., G.R. Brown, and E.D. Brown. 1970. Comparison of factors influencing fruit size in large-fruited and small-fruited clones of strawberry. J. Amer. Soc. Hort. Sci. 95:827-831.

Mudge, K.M., K.R. Narayana, and B.W. Poovaiah. 1981. Control of strawberry fruit set and development with auxins. J. Amer. Soc. Hort. Sci. 106:80-84.

Nascimento, J.R.O., B.K. Higuchi, M.L.P.A. Gómez, R.A. Oshiro, and F.M. Lajolo. 2005. L-Ascorbate biosynthesis in strawberries: L-Galactono-1,4-lactone dehydrogenase expression during fruit development and ripening. Postharvest Bio. Technol. 38:34-42.

Olsson, M.E., J. Ekvall, K.E. Gustavsson, J. Nilsson, D. Pillai, I. Sjoholm, U. Svensson, B. Akesson, and M.G.L. Nyman. 2004. Antioxidants, low molecular weight carbohydrates, and total antioxidant capacity in strawberries (Fragaria $\times$ ananassa): Effects of cultivar, ripening, and storage. J. Agr. Food Chem. 52:2490-2498.

Perkins-Veazie, P. 1995. Growth and ripening of strawberry fruit. Hort. Rev. 17:267-297.

Perkins-Veazie, P.M. and D.J. Huber. 1987. Growth and ripening of strawberry fruit under field conditions. Proc. Fla. State Hort. Soc. 
100:253-256.

Pozo-Insfran, D.D., C.E. Duncan, K.C. Yu, S.T. Talcott, and C.K. Chandler. 2006. Polyphenolics, ascorbic acid, and soluble solids concentrations of strawberry cultivars and selections grown in a winter annual hill production system. J. Amer. Soc. Hort. Sci. 131:89-96

Schwab, W. and T. Raab. 2004. Developmental changes during strawberry fruit ripening and physico-chemical changes during postharvest storage, p. 341-369. In: R. Dirs and S.M. Jain (eds.). Production practices and quality assessment of food crops. Kluwer Academic Publishers, Netherlands

Shamaila, M., T.E. Baumann, G.W. Eaton, W.D. Powrie, and B.J. Skura. 1992. Quality attributes of strawberry cultivars grown in British Columbia. J. Food Sci. 57:696-699.

Spayd, S.E. and J.R. Morris. 1981. Physical and chemical charateristics of puree from once-over harvested strawberries. J. Amer. Soc. Hort. Sci. 106:101-105.

Sturm, K., D. Koron, and F. Stampar. 2003. The composition of fruit of different strawberry varieties depending on maturity stage. Food
Chem. 83:417-422.

Stutte, G.W. and R.L. Darnell. 1987. A non-destructive developmental index of strawberry. HortScience 22:219-221.

Wang, S.Y. and H. Lin. 2000. Antioxidant activity in fruits an leaves of blackberry, raspberry, and strawberry varies with cultivar and developmental stage. J. Agr. Food Chem. 48:140-146.

Williner, M.R., M.E. Pirovani, and D.R. Güemes. 2003. Ellagic acid content in strawberries of different cultivars and ripening stages. J. Sci. Food Agr. 83:842-845.

Woodward, J.R. 1972. Physical and chemical changes in developing strawberry fruits. J. Sci. Food Agr . 23:465-473.

Yamazaki, K. 1982. Nutrient Solution Culture. Pak-kyo Co., Tokyo. (in Japanese)

Yoshida, Y., N. Koyama, and H. Tamura. 2002. Color and anthocyanin composition of strawberry fruit: Changes during fruit development and differences among cultivars, with special reference to the occurrence of pelargonidin 3-malonylglucoside. J. Japan. Soc. Hort. Sci. 71:355-361. 